University of Nebraska - Lincoln

DigitalCommons@University of Nebraska - Lincoln

Fall 2005

\title{
Nurse Gordon on Trial: Those Early Days of the Birth Control Clinic Movement Reconsidered
}

Rose Holz

University of Nebraska-Lincoln, rholz2@unl.edu

Follow this and additional works at: https://digitalcommons.unl.edu/womenstudiespapers

Part of the Feminist, Gender, and Sexuality Studies Commons

Holz, Rose, "Nurse Gordon on Trial: Those Early Days of the Birth Control Clinic Movement Reconsidered" (2005). Papers in Women's and Gender Studies. 3.

https://digitalcommons.unl.edu/womenstudiespapers/3

This Article is brought to you for free and open access by the Women's and Gender Studies Program at DigitalCommons@University of Nebraska - Lincoln. It has been accepted for inclusion in Papers in Women's and Gender Studies by an authorized administrator of DigitalCommons@University of Nebraska - Lincoln. 


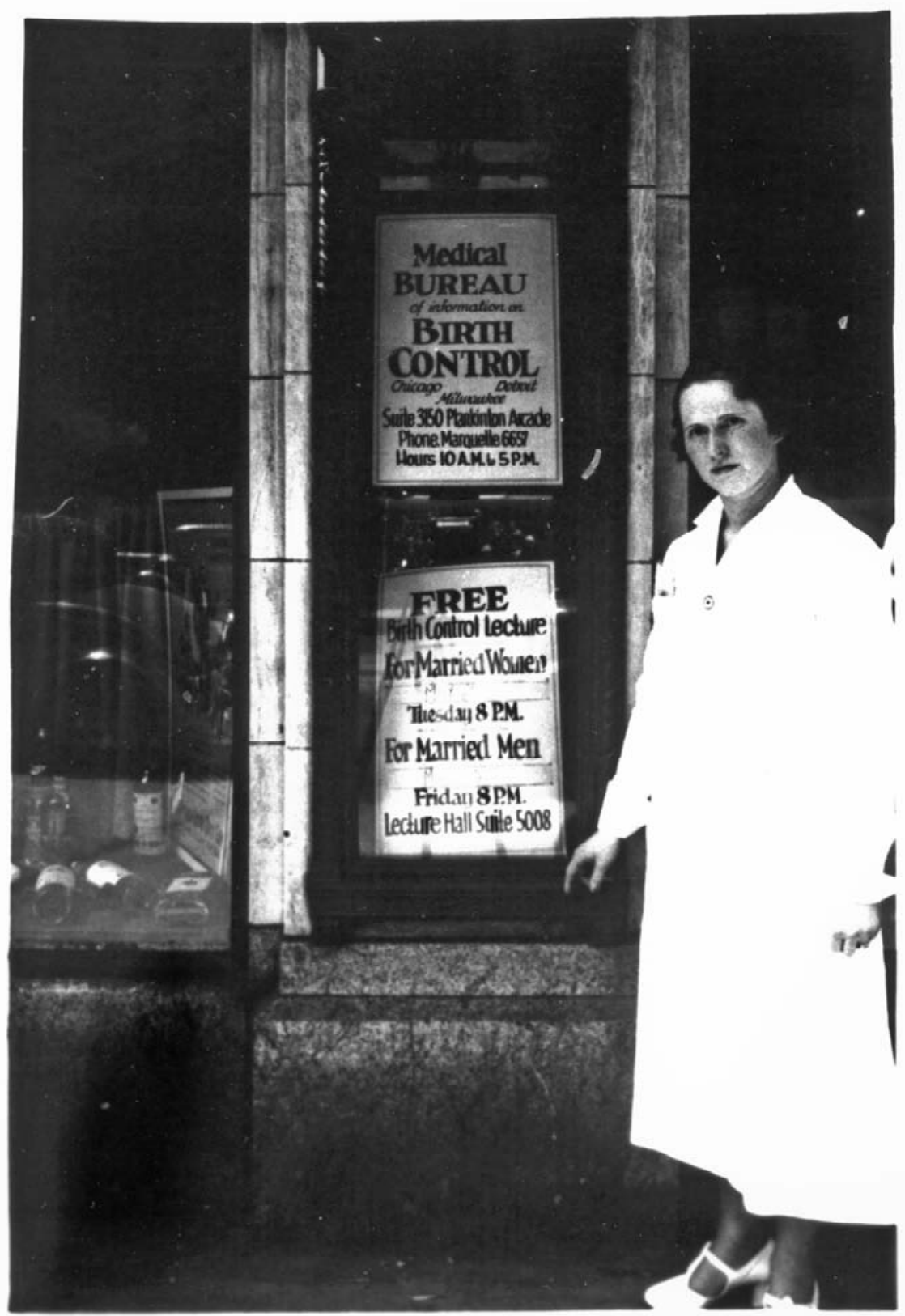

Undated photograph of Nurse Adele Gordon, circa early 1930s, frame 224, reel 108, Margaret Sanger Papers (Library of Congress, Washington, DC). 


\section{NURSE GORDON ON TRIAL: THOSE EARLY DAYS OF THE BIRTH CONTROL CLINIC MOVEMENT RECONSIDERED}

\section{By Rose Holz}

\author{
University of Nebraska, Lincoln
}

It is a story many of us know well. As historian Linda Gordon explained nearly thirty years ago, in the early days of the teens Margaret Sanger was a radical. She talked about sex. She talked about revolution. She criticized doctors. She even opened a clinic in overt defiance of the law. And in this clinic she exercised her skills as a nurse and educated women about birth control. But then, as Gordon's story also goes, by the 1920s Sanger shifted tactics: she softened her critique and she put a doctor in charge of her new facility, with the message that only physicians were qualified to fit women with the diaphragm, though she knew full well how to do it on her own. And so, there ended the radicalism not only of Margaret Sanger but of the birth control clinic movement itself. ${ }^{1}$

But what if this were only part of the story? What if there were other birth control clinics out there which did not adhere to this newly emergent medical model: clinics which used nurses; clinics which used Irregular practitioners; clinics which even had direct ties with the commercial contraceptive world. Furthermore, what if those clinics, which operated in association with the increasingly physician-dominated American Birth Control League, still occasionally threatened to rupture into radicalism themselves, or at least to blur seemingly effortlessly into the world I just described above. And finally, what if Sanger herself continued to dabble in her old habits as well by lending her support to those whom she supposedly should not? As these and other such questions suggest, what I argue here is that it is perhaps time we set aside (for the moment at least) Gordon's brilliant yet oft-told tale so that we might cast our gaze anew upon those early days of the 1920s and '30s. For what I believe we will find as a result is an even richer story, one which reveals not only the breadth of the birth control clinic movement but also the American Birth Control League's efforts to contain it. ${ }^{2}$

To cast such a gaze, we must begin by viewing this world through the lenses ground by historians of medicine. First, we must take seriously what I call "Irregular" birth control clinics (those sponsored by nurses, chiropractors, and commercial entrepreneurs), for to do otherwise would be to perpetuate what the American Birth Control League (ABCL) would have us believe, that such clinics were nothing more than the work of quacks or scoundrels whose only purpose was to profit off their patrons' desperation. ${ }^{3}$ Using the word "Irregular" to describe them is important too. ${ }^{4}$ Among historians of medicine, this is a term to define such practitioners as chiropractors or homeopaths whom the Regular medical profession (the American Medical Association for example) regarded in less than favorable ways. My use of the term, admittedly, covers a much broader range of providers, but I do so for good reason. In part, grouping these many individuals together shows the similarity of their status with respect to organized medicine, 
as the American Medical Association (AMA) had about as much love for the entrepreneur or the self-reliant nurse as it did the Irregular practitioner. But to group them together, under this heading especially, captures also organized medicine's long-standing campaign against this world of Irregular providers, a campaign in which the American Birth Control League, in its efforts to win the backing of the AMA, was now becoming an avid participant. ${ }^{5}$

But we cannot put our lenses down there, for what this new gaze also requires is a return to those clinics which dispensed things other than birth control. Indeed, although the birth control clinic was unique in the particular kind of services it offered, it operated nonetheless within a larger clinic movement more generally, a movement which sought to provide a wide range of medical services and which also consisted of a similar breadth in form as I argue the birth control clinic did. And once again, what is significant is organized medicine's response. As this larger clinic movement grew in size and strength, so too did the medical profession opposition's to it, and by the 1930s there came a call from among doctors to get these local facilities under direct medical control. Therein lies the key to one part of my story, for only in light of this can we more fully understand why, in 1935, the American Birth Control League put into place its own standards for clinic certification, standards which clearly hoped to establish its clinics' allegiance to the professional medical world. ${ }^{6}$ Put another way, convincing organized medicine of birth control's legitimacy was only part of ABCL's battle; convincing it of the legitimacy of its clinics was important as well.

But what we must also consider is the significance of Nurse Adele Gordon herself, a woman who began her birth control clinic career by laboring in a commercial setting, only to branch out on her own later on. What her story reveals, in part, are the limitations of the historiography on twentieth-century birth control, in particular that on the American Birth Control League and its related national birth control organizations. ${ }^{7}$ Although there has in recent years been an effort to move beyond the activities at the national level by documenting life at the local, still privileged, however, are those clinics which operated in conjunction with these national organizations, and still often assumed is that all birth control clinics sought to achieve such status. ${ }^{8}$ Gordon's operation, as do others like hers, reveals this not always to be the case. But what Nurse Gordon's story also demonstrates is that, even by the 1930s, not all was yet set in stone in terms of what constituted "proper" birth control clinic behavior. Indeed, although the provision of the diaphragm had become a cornerstone of this new institution, there remained significant malleability where other clinic operations were concerned. It was this malleability, therefore, which the American Birth Control League sought to contain; and it was this malleability which also lay behind the League's push for clinic certification, giving rise in turn to a striking irony: that, despite the organization's efforts to encourage the establishment of clinics elsewhere in the nation, its push for certification meant simultaneously the vilification of those which did not adhere to its new rules. Hence when I say, as I did in the title of this piece, that Nurse Gordon was "on trial," I say so because she was, and in two senses of the phrase: not only was she on trial in the courts but in many respects she was also on trial within the organized birth control clinic movement itself. ${ }^{9}$ 


\section{Nurse Gordon and the Irregular Birth Control Clinic Movement}

Adele Gordon was an impressive individual. She was compassionate, charismatic, and driven to do her job well. Born in the year 1900, she would go on to attend the Illinois Training School where she earned her degree to engage in the nursing profession. She then spent a few years at the University of Chicago, studying to become a physician. But for reasons unknown, she chose not to complete this particular line of study and decided instead to work as a public health nurse. Her skills, compassion, and dedication did not go unnoticed by those around her however, as not only did she receive several scholarships but she also earned the admiration of at least one prestigious physician (Dr. J. F. Meyer) with whom she worked in the charity ward at Chicago's Cook County Hospital.

But Gordon, it seems, was a restless woman, and it would not be long before change for her was once again at hand. After laboring for several years as a public health nurse, by her late twenties she decided to secure employment with a company known as Lanteen Laboratories. And Lanteen Laboratories, I should further explain, was a Chicago-based contraceptive manufacturer, which also just so happened to operate a handful of birth control clinics in various Midwestern locations. It was in these clinics, then, where Gordon now worked, and for three years her job was to fit women with the diaphragm inside what the company called its "Medical Bureaus of Birth Control Information." The hard worker that she was, it should come as little surprise, moreover, that she would quickly prove herself a valuable employee, one who deserved to be rewarded. And in the early 1930s, that was precisely what happened. Her employers had decided to open yet another clinic, and because Gordon had earned the reputation of being "a good educational worker and lecturer," they decided to put her in charge of their new facility in the state of Wisconsin. Sometime in 1932, then, Gordon was transferred north, and on July 5, the Milwaukee branch of the Medical Bureau of Birth Control Information opened for business. ${ }^{10}$

The clinic she ran was a visible one. With Lucina Irish Brown as its secretary, the facility operated at $161 \mathrm{Wisconsin}$ Avenue, inside the Plankinton Arcade Building. The Plankinton Arcade Building (as it was then and still is today) was a massive commercial space, the site of many businesses and retail outlets which constituted the heart of the city's downtown. It was here, then, that Nurse Gordon operated her clinic and, like her fellow entrepreneurs, she placed a sign in the window advertising the services her Medical Bureau of Birth Control Information had to offer. As the sign (which can be seen in the cover photograph to this piece) read: hours of operation were Monday through Saturday, 10am to $5 \mathrm{pm}$; free lectures about birth control were available too. Those of less comfortable means were also invited to visit the clinic, and although they were only to attend hours specifically set aside for them, they needed only pay as much, or as little, as they could. ${ }^{11}$

The clinic she ran would also become a bustling one. Seven months after its opening, Gordon was able to report on three hundred cases (which was not bad by clinic standards); and if her lectures were any indication of the continued popularity of her work, she was doing quite well, as by 1935 some three hun- 
dred women listened to her speak in one of her regularly scheduled talks about birth control. Furthermore, with respect to the background of the women who attended her clinic, the data suggest a pattern similar to those who attended clinics elsewhere in the nation. For example, where religion was concerned, the largest group drew from Protestant denominations (66\%), with Catholics coming in as the second largest (25\%). Where reproductive matters were concerned: many had at least one child (roughly $80 \%$ ); many reported to having induced (on their own or with someone else's assistance) at least one abortion (82\%); and many also cited a variety of reasons as to why they wanted birth control, though the most common (72\%) was "economic condition." And finally, where race and ethnicity were concerned - the statistic which tended to vary the most from clinic to clinic (as a result most likely of the neighborhood in which it operated) - most of the patients at the Milwaukee Medical Bureau (89\%) were what the forms referred to as "American white." 12

But success for the clinic did not come easily; nor did it translate into much money. During the first one-and-a-half years of its existence, the facility was dependent upon the Chicago office, which paid light, rent, and phone. As Gordon would explain, times were hard and "the clinic showed very little chance of becoming self-supporting." Moreover, the 1933 passage of the O'Malley bill (a bill sponsored, reputedly, by local Catholics and which restricted the sale of birth control to doctors and registered pharmacists) further threatened the clinic's existence. It was, in fact, these two factors combined which in 1934 led Gordon's employers back in Chicago to tell her they were going to shut the Milwaukee facility down. ${ }^{13}$

But the clinic had become more to Gordon than just "a livelihood;" it had become a passion, and although a job back at the Chicago branch would have been what she described as a "far more comfortable" existence, she could not abandon what she worked so hard to create. In addition, the unlikelihood that another such clinic might be established by, say, one of the local women's groups, further worried Gordon, for not only had she encountered considerable disinterest among such organizations, but downright hostility. It was then that Gordon decided to take over the clinic herself; and it was also then that Gordon's husband paid a visit to the local district attorney's office to find out how exactly the recently passed O'Malley bill applied to their work. Unable to meet with the D.A., he learned through the secretary, however, that they need not worry about their clinic operations. ${ }^{14}$ Just to make sure, though, the Gordons decided to operate their clinic in this way: it was Adele's services for which the patients paid; supplies came free, or at least this is what they would later claim. ${ }^{15}$

In many ways, then, Adele's work could be described by some as quite radical (as will become more clear in a moment), but as far as the birth control clinic movement more generally was concerned, what she did was really quite conservative, if not also very much in line with what the American Birth Control League hoped its clinics would do as well. For example, not only did Gordon refuse to provide abortions, she also refused to serve the unwed. As she would explain, "there has never been a pregnant woman examined, or an unmarried woman fitted." That she would further add, in explanation of this last point, how her clinic "has been purely and ethically Birth Control" suggests too that she shared in the League's more stringent definition of this much debated term. ${ }^{16}$ 
In addition, Gordon's meticulous care in securing medical histories on each of her patients, which the clinic's secretary then tabulated into neat tables of analysis, suggests their shared interest in the more scientific side of birth control. ${ }^{17}$ And finally, that Gordon carefully cultivated ties with local physicians, medical institutions, and relief agencies, who in turn sent her patients by way of referral, shows how she understood their significance to the successful operation of a local birth control clinic as well. ${ }^{18}$ In fact, all of these practices were the very same strategies the American Birth Control League promoted on the pages of the Birth Control Review, the organization's newsletter which Gordon herself took the time to read. ${ }^{19}$ In other words, and as far as clinics go, the only sign of her radicalism was this: Nurse Gordon was Nurse Gordon; and even though she had branched out on her own, Nurse Gordon continued to maintain ties with the commercial contraceptive world.

But Gordon was not alone in carrying out such work. Her employer (Rufus Riddlesbarger of Lanteen Laboratories) of course operated several other clinics. And when taken together, Riddlesbarger's various clinic operations constituted a "glorious chain" of its own - to borrow the phrasing once used by Margaret Sanger - which neatly dotted the perimeter of Lake Michigan. ${ }^{20}$ Detroit was home to one of these facilities. Chicago home to the other. It was, in fact, in the city of Chicago where Riddlesbarger's business first began, with the clinic established there constituting his flagship operation. First established in the late 1920s, the Chicago Medical Bureau provided services in the city's fashionable downtown, not too unlike the one he opened several years later under Gordon's care in Milwaukee. The Chicago clinic was also quite successful, for not only did it last for at least ten years (if not more), but it also boasted a minimum clientele of 1,300 women per year. ${ }^{21}$

But then there were the facilities operated by others. Indeed, the flurry of clinic activity in Chicago is striking. As one look in the local telephone directory, under the heading of "birth control," reveals: Bureau of Birth Control Information (1511 E. 53rd Street), Illinois League of Birth Control Clinics (203 N. Wabash), Medical Bureau of Birth Control Information (190 N. State Street), and Woman's Bureau of Birth Control Information (32 W. Randolph). ${ }^{21}$ Equally striking are their locations. As any geographically-inclined Chicagoan would be quick to point out: the clinics' close proximity in the phonebook was matched only by their close proximity in the city itself. And with one exception, these facilities also operated not only within several blocks of each other but also within several blocks of the main office and busiest clinic of the ABCL-associated Illinois Birth Control League itself. In other words, and in the city of Chicago at least, competition among clinics was perhaps more vigorous than we might have previously imagined.

Yet this does also raise the question of just how common this phenomenon actually was. Determining the existence of other such Irregular facilities has been difficult, and it is made only more difficult by Chicago's seeming uniqueness in its use of the "birth control" heading in the local telephone directory. Phone books for other major metropolitan areas (such as Los Angeles, New York, and Washington, DC) had no comparable designations, and why Chicago did while these other cities did not is not entirely clear. But there can be found shreds of evidence suggesting the presence of at least a few more such facilities else- 
where in the nation. There is rumor of a clinic in New York City, which can be gleaned from one letter written between birth control proponents in 1933; and there is a rumor of a facility in Los Angeles, as evidenced by one of the individual listings in the city's telephone directory, several years earlier. ${ }^{23}$ But these are just scraps of information, and more research needs to be done to determine just how widespread this Irregular birth control clinic movement was. Yet their significance remains important nonetheless, for their presence (scant or pervasive as it may have been) would be enough to provoke a response from the American Birth Control League.

So what was it, then, which seemed to distinguish these Irregular facilities from those which were more Regular (hence more "medical") in nature? First and foremost were the types of practitioners who worked within. The Regular clinics of the League were supposedly run by Regular doctors, but in these Irregular facilities this was not always the case. ${ }^{24}$ Nurses, for example, were common in the clinics I have found, and not just nurses whose job was to assist the doctor (as organized medicine hoped to define their position), but nurses who conducted the entire examination and prescription process themselves, and who only consulted the doctor when they felt it was necessary. ${ }^{25}$ Chiropractors could also be found within these Irregular clinics, as was the case with the Woman's Bureau whose operations were directed by a practitioner by the name of Dr. Dennis Blood. ${ }^{26}$

Then, too, there was the matter of publicity, an issue which rippled not only into questions of propriety but also into discussions about service to the unwed. League clinics were supposed to announce their facilities quietly, if not also tactfully, in part to avoid breaking the law but also to ensure that news of such services would "not fall into the hands of high school children and unmarried girls, thereby doing," as the vice president of the Illinois Birth Control League would further write, "unlimited harm." ${ }^{27}$ Such discretion, however, was not necessarily the case where Irregular facilities were concerned. Advertisements for the Lanteen-sponsored Medical Bureaus appeared seemingly everywhere: on the radio, in form letters (mailed out both to potential female clients as well as to potential professional referrers, doctors themselves), in drugstores (across the nation), and even inside the boxes of sanitary napkins. ${ }^{28}$ But the Woman's Bureau was overt too. Not only did those associated with the clinic leaflet pedestrians at downtown street corners, but they also left stacks of fliers inside downtown office buildings, fliers which plainly illustrated a diaphragm resting snugly against a cervix and the insertion of spermicidal jelly from a tube cleverly bearing the clinic's name. ${ }^{29}$ All of this, in turn, reveals a great deal about the various views about sex. While League clinics were supposed to promote "wholesome attitudes" about it and also to leave such discussions to the staff physician, Irregular clinics seemed to think otherwise. ${ }^{30}$ In fact, there is even evidence to suggest that at least one practitioner inside the Chicago Medical Bureau had few reservations about serving the unwed. Further revealing still were her readily-expressed opinions about the importance of female sexual fulfillment, views which resonated with those of Sanger in her earlier, more radical, days. $^{31}$

But in determining the many differences between Irregular clinics and Regular ones, there remains yet one more important distinction: the existence of 
commercial connections, if not also business-like practices. While the Regular clinics of the League were charitable operations, Irregular clinics-as was especially the case with the commercially-sponsored Medical Bureaus-often were not, and customers were therefore expected to pay for what they got. ${ }^{32}$ Moreover, when it came to the method itself, the company's clinics prescribed only what the company manufactured. ${ }^{33}$ Indeed, the chain of clinics (like the rest of the company Riddlesbarger ran) was a business, and he ran it with a businessman's flair, as the following exchange between he and Margaret Sanger illustrates. "You may be assured," Riddlesbarger wrote in explanation of the possibility that he would expand to the East Coast, "that we would not consider opening a branch in New York City without first consulting with you." "Such [an operation]," he further added with an air of entrepreneurial congeniality, "would be opened only on arrangement of friendly cooperation with your clinic." Put another way, although he believed there was a "need for a clinic there," he would not hone in on what he regarded as Sanger's territory. ${ }^{34}$

It would be a mistake, however, to overdraw the distinctions I have made here, for to do so would only conceal the blurriness of this birth control clinic world. Regular clinics could, in fact, sometimes behave quite Irregularly. For example, that the League' newsletter, the Birth Control Review, consistently reminded its readers that "no trained worker will attempt to give contraceptive advice to a client" suggests that some clinic workers occasionally did..$^{35}$ The same could also be said about the organization's exhortations about the need to promote "wholesome" attitudes about sexuality, as public words could differ from private practice. ${ }^{36}$ Nor were these charitable League clinics averse to charging their wealthier patients fees for what they received, fees which were in line with the going market rate. ${ }^{37}$ And equally important too were the various views about abortion. Although, officially, League clinics were to avoid the procedure entirely, there is evidence to suggest that some clinics occasionally broke the rules. ${ }^{38}$ Hence the Regular clinics of the League could easily be mistaken for their Irregular counterparts. But of course this fuzziness could work both ways, as Nurse Gordon's work so vividly revealed. Although some of her fellow Irregular colleagues may have espoused more liberal views about service to the unwed or the provision of abortion, she expressly did not. Irregular clinics, in other words, could sometimes behave quite Regularly.

Where services were concerned, therefore, the boundaries between these various birth control clinics were blurry indeed. In fact, the only thing more indistinguishable were the names of the clinics themselves. A list drawn from "both sides" of this clinic movement makes this maddeningly clear:

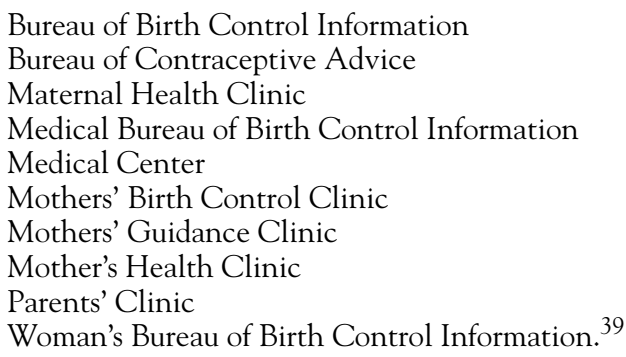


Telling the difference by those engaged in the field must have been difficult enough; telling the difference by consumers themselves (or anybody else for the matter) must have been virtually impossible.

And it was precisely this muddiness which troubled the League so. Looking to distance itself from Irregular providers, looking to distance itself from nurses and commercial entrepreneurs, and looking also to promote conservative attitudes about sex, the League hoped to win over the powerful AMA. The only problem was that, despite the League's efforts, the birth control clinic's more radical tendencies seemed always to persist, if not in one form then in another. Hence, in its efforts to win the backing of the AMA, the League found itself faced with two battles to wage: in part to win the medical organization's support for birth control, but also to win its recognition of the birth control clinic itself. It is on that note, then, that we should pause in our story about Nurse Gordon so that we might cast our gaze upon the broader history of medicine, for there we will see the larger clinic movement of which Gordon's work was but one small part.

\section{Clinics Even More, If Not Also That Nasty "Clinic Habit"}

Back in 1974, when Charles Rosenberg wrote his now classic piece entitled, "Social Class and Medical Care in Nineteenth-Century America: The Rise and Fall of the Dispensary," he made several enormous contributions to the field. In part, he documented a previously undocumented institution. But what he also did was to place its existence within its larger social context, which was an important reminder to help fuel the then nascent field of the social history of medicine. It is, however, his specific argument about the dispensary itself which concerns me here. As Rosenberg explained, the institution's late eighteenth century rise, as well as its proliferation in the hundred years which followed, was due largely to its usefulness to the medical profession, which saw in it not only a great way to teach medicine but also a great way to advance medical careers. But therein also lay, as Rosenberg further explained, the seeds to the dispensary's early twentieth century decline, for once this usefulness waned, so too did the charitable institution itself. And by the 1920s, it had virtually disappeared, becoming, as Rosenberg wrote, "increasingly submerged in the outpatient departments of urban hospitals." ${ }^{40}$ For all the accuracy of this argument, a doctor back then might have said something a bit different. A doctor back then might have said: if only this were the case.

Indeed, although the dispensary may have died, in its ashes the clinic of the twentieth century was born, and unlike the dispensary before it, doctors were necessarily central neither to its rise nor to its popularity. That was the product of other folks, not least among them the variety of individuals who organized them (who drew from both lay and professional backgrounds), if not also the patients themselves who by the 1930s found themselves increasingly faced with the economic hardships of Depression-era days. In other words, by the 1930s, though the competition posed by the dispensary was gone, the competition posed by the clinic had emerged, and because the medical profession was unable to buck this trend of clinic popularity, a trend referred to more derisively by some as this "clinic habit," it resorted to the only option it had left. And that was to get this "new" institution under direct medical control, or at least to try. ${ }^{41}$ 
Admittedly, there is no easy way to define the clinic of the twentieth century, but that is again precisely part of the story here, as the medical profession struggled with it as well. In its previous incarnations, the clinic already had a long history within the practice of medicine, one which was filled with enough tales to scientific progress and discovery to make any doctor's heart swell with pride. For example, in his presidential address before the 1933 annual meeting of the AMA, Dr. Dean Lewis would wax poetic about the institution's eighteenth century rise in the hospitals of Europe, which ushered in not only a new understanding of disease but an excellent way to train physicians. ${ }^{42}$ But such pride belied other concerns, for with the dawning of the twentieth century, it seemed that the glorious clinic of old had been replaced, as some doctors would complain, with something which was far less noble in nature. As another physician would heatedly note: yes, the clinic had important educational roots, but "in its development the clinic has wandered far away from its origin," for (as he further added) "today the clinic stands as malevolently in the path of medical progress and prosperity as once it held out a benevolent ... hand" to guide it. The doctor then went on to add with even further disgust, "the clinic has become as ubiquitous as the mosquito in a swamp and equally pestiferous." 43

In some ways, perhaps, the doctor had a point. As Paul Starr and others have shown us, clinics had indeed become more common. ${ }^{44}$ Throughout the Progressive era, the establishment of clinics had become an important part of the many campaigns for public health reform, and it was a trend which continued into the 1930s as the economic hardships of the Depression made their presence even more necessary. Equally significant were the many different kinds of services these new clinics provided. There were well-baby clinics, tuberculosis clinics, social hygiene clinics, crippled children's clinics, and of course, birth control clinics, to name just a few. That many of these institutions seemed to fall beyond the grasp of the medical profession was true as well, for it was often the profession's failure to establish such facilities which motivated others-lay individuals, nurses, social workers, doctors (radical Regulars and Irregulars), even entrepreneurs-to create their own. ${ }^{45}$

But it was not simply those clinics which fell beyond the realm of organized medicine which troubled doctors so; it was also those which were intimately bound up with it too. For with the growth of hospitals came also the growth of hospital clinics, and in the eyes of many private practitioners this constituted yet another source of competition in what they saw as the much-beleaguered world of the private practice of medicine. ${ }^{46}$ And so, although it might seem odd to mention all of these different kinds of clinics in one breath, I do so only because doctors themselves often did so too. Hence the situation was truly a complicated one, with few easy answers as to what the clinic really was, not to mention what role it was to play in the larger practice of medicine.

Within this growing debate, it was the Illinois State Medical Society (ISMS) which was among the clinic's most vociferous opponents, and it was also the Illinois State Medical Society which in turn spearheaded some of the earliest campaigns to take control of the situation by working to put doctors in charge. As early as 1923, the state medical society had already begun to complain formally about what it called "Free Hospitalization and the Maintenance of Indiscriminate Free Clinics," which it listed alongside the other things it found trouble- 
some as well: the "Lay Dictation of Medical Practice," "State Medicine," "Federal Aid," the "Overtrained Usurping Nurse," "Compulsory Health Insurance," "Workman's Compensation," "sex license" through the infiltration of communism, and also the Sheppard-Towner Maternity Act. ${ }^{47}$ One year later, the Illinois Medical Society put words into action by establishing a set of rules about what it described as "the conduct of clinics in the state of Illinois." Central to the organization's new policies were two things: first, that clinics serve only the indigent poor; and second, that they operate either with the consent of the local medical society, or, better yet, under its direct supervision. The ISMS then urged each county society to get involved, not only by establishing its own policies about clinic behavior but also by seeing that they were properly "enforced." 48

Such rules were not without precedents however. The Illinois Tuberculosis Association, an organization which operated clinics of its own, had adopted a similar set of policies back in 1917, policies which the organization then made more stringent several years later. ${ }^{49}$ Tellingly, the reasons behind these tougher guidelines, as they were explained by the organization's medical director (Dr. George Palmer), suggest their significance in earning the support of the professional medical world. "'Reasonable compliance' with the opinions of the medical profession," he wrote in a 1925 issue of the Illinois Medical Journal, was not enough. Only under this new "plan," he further explained, could it remove the "last remaining trace of doubt as to the high ethical standards of [the organization's] clinical service." But with such rules the Illinois Tuberculosis Association was unusual, which even Palmer himself was quick to note. Doctors had always been in charge within this particular organization; in fact they were they were the ones who helped establish it. ${ }^{50}$ Where other organizations were concerned, this was not always the case. In 1929, then, five years after the Illinois State Medical Society first established its rules governing clinic behavior (and two years after the society rearticulated these rules on the pages of its medical journal), the state medical society decided to take its case to the highest medical authorities in the land: the AMA itself. ${ }^{51}$

"Whereas, There is a rapidly growing tendency of organizations controlled by laymen to enter into the practice of medicine," explained Illinois' Dr. William Allen Pusey in his 1929 resolution to the AMA's House of Delegates, and "Whereas There are numerous new problems arising from this movement, therefore be it Resolved," Pusey further demanded, that the AMA issue "a comprehensive statement" concerning not only the practice of medicine by "clinics" but also "the relationship of physicians thereto." 52 In its reply the AMA was concerned, though evasive. The scope of the resolution, the AMA understandably explained, made an immediate evaluation impossible, but then it hinted that in the future "some definite policies" might be established. "In the meantime," the AMA urged, local societies should monitor carefully the situation in their own communities and submit "all available information" to the national medical organization to assist in its evaluation process. ${ }^{53}$

The Illinois State Medical Society followed up on the AMA's recommendations with gusto. In the years following, not only did the state organization's professional journal continue to publish articles lambasting the clinic movement, but local members themselves kept tabs on clinic developments within their own communities, and then reported back what they found. In fact, it was 
a source of great pride for one district when, at the 1934 state annual meeting, it was able to announce what it called "the absence of objectionable clinics." Even the women's auxiliary lent a hand. "Every physician's wife," the women's organization announced at the 1931 annual meeting, should "use her influence to prevent the unfair competition of badly managed welfare clinics which in the final analysis are detrimental to public and profession alike." 55

As we know, however, the matter of clinics was not the only pressing issue for organized medicine at this point in time; the matter of birth control was heating up too. And while the Illinois State Medical Society was pushing the AMA to consider stricter guidelines on clinics, the American Birth Control League (as well as Sanger's newly established National Committee for Federal Legislation on Birth Control) was lobbying to get the organization's support for contraceptives as well. They seemed to be making some headway too. At the AMA meeting in 1927, for example, one committee recommended "the alteration of existing laws wherever necessary so that the physicians may legally give contraceptive information to their patients." 56 That same year, the Journal of the American Medical Association (JAMA) reported favorably on a birth control clinic operated in association with the Johns Hopkins School of Medicine. Granted, the clinic was described as "purely an association of medical men" who were also in charge of its operation, a characterization which hardly indicated an endorsement of birth control clinics more generally. But it did at least suggest a slow shift in attitudes where the provision of contraceptives was concerned. ${ }^{57}$ Even more telling was the sympathetic coverage JAMA devoted to the 1929 raid on Sanger's clinic in New York, revealing further still how the AMA was slowly coming around, and how it would continue to do so in the decade that followed. ${ }^{58}$ But then something happened, something which revealed how trouble was elsewhere still afoot. On March 5, 1935, Nurse Adele Gordon and her husband John were arrested for selling birth control in their Milwaukee-based clinic.

\section{Raid in Milwaukee}

It is a familiar story. On February 19, 1935, two women entered Milwaukee's Medical Bureau of Birth Control Information looking for assistance. The first woman with whom Nurse Gordon spoke gave her name as Mrs. Norma Drossen. Drossen was married, her husband (Alfred) was a medical student at Marquette University, and together they had one child, who was one-and-a-half years old. However, it was for precisely these reasons that Drossen wanted help because, as she would further explain, they "could not afford another baby at this time." With no "reason in the world to question her word," as Gordon would later write, the nurse proceeded to examine the woman and fit her with a diaphragm, for which she then charged her patient a total of five dollars. But Mrs. Drossen was not alone in her desire for assistance; her young friend wanted help too, but because she was unmarried, Gordon refused to serve her. With no further ado, the two women then left, without incident but with Mrs. Drossen's newly obtained supplies of contraception in-hand. Two-and-a-half weeks would pass, and Drossen would once again make her way to the clinic. But unlike the last time, when she was accompanied by her unwed friend, this time she had with her three men (two detectives and one chief investigator), none of whom, as 
Gordon would quickly learn, was interested in securing the services she had to offer. Indeed, Norma Drossen was not Norma Drossen, but rather Janet Drozniakewicz. And Janet Drozniakewicz was more than the humble wife of a struggling medical student. She was also a spy. In other words, Gordon's clinic had been the target of a raid, and as a result both she and her husband were arrested for violating the O'Malley law. ${ }^{59}$

Exactly who was all behind this raid remains open for debate, though clearly it had at least the involvement of the district attorney's office, if not also perhaps the state medical society, the state board of health, church groups, and even possibly a local nurse or two. The reports are wildly conflicting. ${ }^{60}$ But whatever the exact source, it always came back to one man in particular, a man by the name of Walter Drews, who had connections with both the local medical society and the state health agency. Drews had been interested in the clinic for some time. As he would later explain, he had visited the facility once before, in response to what he described as "complaints from several church groups" as well as a "nursing organization." On his first trip to investigate, then, Drews "asked to see the doctor in charge," only to learn from Adele's husband that none was available. Worse still, in Drews' opinion, John Gordon offered to provide assistance nonetheless. ${ }^{61}$ The lack of a physician was not the only thing which bothered Drews however; he also wondered if the clinic might be serving the unwed, which, if true, would serve as a great way to "trap" those who ran the facility, as Adele herself would later perceptively note. ${ }^{62}$ Thus the plan to send two women (one married and one not) to lay the groundwork was born; and thus too the raid which took place in the weeks that followed. And at the head of this operation was none other than Drews himself. On that fateful day, then, of March 5, 1935, this is what happened. Walter Drews and his associates (the two detectives plus the former Mrs. Drossen) entered the clinic and informed the Gordons that their presence was required for immediate questioning by the district attorney's office. After seizing the clinic's contraceptive supplies, Drews and his associates then proceeded by squad car to escort the couple away. ${ }^{63}$ Arraignment by the district court quickly followed, whereupon Adele and her husband John posted bail ( $\$ 750$ each) and awaited their separate trials. ${ }^{64}$

In the wake of their arrests they did not sit idly by however, and Nurse Gordon (along with her supporters) sprung immediately into action. They began by printing up fliers in which they asked not only for donations but public outrage. "Birth control is at stake in the State of Wisconsin," Gordon's notice read. "Are you willing to have this Bureau close," or, as she further challenged, "are you willing to stand back [sic] and fight." Readers were then encouraged to attend Gordon's next lecture, where, instead of discussing the details of birth control, she would describe the recent turn-of-events. ${ }^{65}$ But this was only part of their campaign. They wrote letters to local newspapers, ${ }^{66}$ and newspapers responded with sympathetic accounts. ${ }^{67}$ They contacted Gordon's former employer $(\mathrm{Ru}$ fus Riddlesbarger), who in turn offered to help finance her defense. ${ }^{68}$ They also secured the support of a local labor organization (the Milwaukee district of the International Labor Defense), which then contacted the American Civil Liberties Union. ${ }^{69}$ They even turned to the big names of the birth control movement itself, with Lucina Irish Brown (the Milwaukee clinic's former secretary) writing to Marguerite Benson (then head of the American Birth Control League), ${ }^{70}$ 
and Nurse Gordon sending out word to the biggest name of them all: Margaret Sanger herself.

The flurry of correspondence which ensued between Gordon and Sanger is striking, revealing in part a deep camaraderie but also the persistence of Sanger's more radical tendencies, in particular her faith in the nursing profession. In the weeks preceding, the two women had already been in contact with each other, but their exchanges reflected only a professional cordiality. ${ }^{71}$ However, when Gordon relayed the news of her arrest, Sanger's passions were aroused. "Your letter of March 6th concerning your arrest received," Sanger replied without delay, "and I certainly feel that all of the women in the State should rise up in indignation and support you." Sanger then proceeded to give legal advice, whereupon she emphatically stressed the capabilities of what she called "a good trained nurse." She then ended her letter with the following words of heartfelt support: "wishing you success and courage, and do not be overcome ... I am deeply interested and wish you the best of luck." ${ }^{\prime 2}$

This was only the first of many exchanges. In the weeks that followed, Gordon not only kept Sanger apprised of her legal predicament but she also shared with her the many details of her work. The bond she felt with Sanger is moving. "I could not help but think of our analogous experience-yours in Brownsville in 1916, mine in Milwaukee 1935," Gordon wrote in the days leading up to her trial, to which she added with even further eloquence: "Aside from the brass buttons[,] mine was detectives, yours the 'Black Maria', mine a squad car. Who says we haven't made Progress!"73 In another letter dated several days later, she would have this to say:

I'm sure you understand all. Perhaps there's no one who understands any better. I hope in some time to come (perhaps 19 or 20 yrs as it is in our case) that I may help some nurse who has 'taken the ride'-Or shall I better say that birth control will be so far advanced that such treatment would be laughable. ${ }^{74}$

Sanger seems to have been similarly moved. Upon learning, in one of Gordon's letters, how it was her experiences as a public health nurse which contributed to her conversion to the birth control cause, Sanger thoughtfully noted in the margins how this was when she became interested in it too. ${ }^{75}$ Even more importantly, with Sanger's sympathy came action. Not only did she instruct her staff at the National Committee for Legislation on Birth Control (the organization which Sanger now headed since her 1929 departure from the American Birth Control League) to begin an immediate letter-writing campaign to the women's organizations of Milwaukee, but she even offered to speak at a rally proposed by the Wisconsin Workers Committee of the Unemployed. ${ }^{76}$

Sanger's involvement, as well as Gordon's various other sources of support, are thus remarkably telling. Here we see, for example, Sanger acting in ways more indicative of her radical days: she emphasized the competence of nurses; she made ties with labor organizations; and she also put aside her reservations about Gordon's connections to the commercial contraceptive world. As she wrote, "Ordinarily I would not ... support such a commercial institution ... but I believe that in the time of attack that we must all stand together and fight the enemy," and "not," as she further explained, "split hairs on the technicalities" but rather "stand together on the principles." "77 Granted, the sexual radicalism 
of her rhetoric is muted, as are the more stridently feminist undercurrents, but some of her other ideas seem to have persisted. Furthermore, what we also see is this: the organizations which stood in Sanger's way in the teens, now stood in Gordon's way in the 1930s. Indeed, despite Sanger's efforts to enlist the support of the local women's groups in Milwaukee, they kept their distance where Adele Gordon was concerned. ${ }^{78}$ And so, it was not the more "respectable" organizations which came to Gordon's aid, but those which were more radical in nature. And when the week of Adele's trial finally came, it was the local labor group which helped pack the court with sympathetic bystanders.

Though intense, the proceedings were brief, lasting only four days. On Monday, April 1, jury selection began. Of the six chosen, five were men; one a woman; four were Catholic; and all were married. The judge (the honorable A.J. Hedding) was Catholic too. The charges against Gordon were as follows: "advertising indecent articles for sale;" "displaying indecent articles to the public;" "having indecent articles in [her] possession with intent to sell;" and "the sale of indecent articles not being registered physicians, pharmacists or surgeons." With testimony set to begin to following day, Gordon harbored little hope. ${ }^{80}$ But her fears were not born out. Despite what the chief investigator (Walter Drews) and his fellow spies had to say, the district attorney could not seem to build a case against her, leastwise he could not quell the strength of her convictions. Indeed, although her defense rested in part on the (rather dubious) argument that it was not the supplies for which Drossen paid but rather the services, it was Gordon's impassioned testimony about the necessity of birth control (if not also her competence in providing it) which seemed to carry the most weight. In his closing arguments, then, the district attorney must have already suspected the worst. "Forget your feelings," Arthur Schmidt reportedly cautioned, and "judge the case on the facts," to which he further added, "[the law] has been violated, and it must be enforced." ${ }^{\prime 1}$ But even the judge himself seemed swayed by what he heard. "If [your are] in doubt," he told the jury in another paraphrased account, "the verdict should be for acquittal," to which he further added the following instructions: "common sense," rather than an "attempt to discuss the technicalities of the law," should form the basis of your decision. ${ }^{82}$ Twenty-five minutes later, the jury returned, Adele's acquittal in-hand. Upon hearing the news, the crowd rushed forward to express their hearty congratulations. ${ }^{83}$ Thirteen days later, John Gordon was acquitted as well. ${ }^{84}$

\section{"Bona Fide" Clinics}

Although the district attorney was unsuccessful in his case against Nurse Gordon, in his arguments against her lay a remarkably telling statement about the larger story which was now taking place. As he sought desperately to stem the flood of sympathy which Gordon seemed so passionately to enlist, he cautioned the courtroom with the following words: "Birth control," he reportedly said, "is not on trial, but Adele Gordon is." ${ }^{85}$ Where the American Birth Control League was concerned, there could have been no more apt way to put it, for, in the immediate wake of Gordon's acquittal, the League worked in a variety of ways to shore up the legitimacy of what it regarded as the only true birth control clinic movement in the nation, that which adhered to its strict new medical rules. ${ }^{86}$ 
The League's efforts involved several facets. In part they included, in May of 1935, the implementation of standards for clinic certification, standards which not only forbid commercial connections but which also insisted upon the use of Regular physicians (and only Regular physicians) to run clinic operations. Singled out directly, therefore, were the practices of Adele Gordon and her fellow Irregular providers. ${ }^{87}$ But what the League also did was to launch a campaign to discredit those clinics which did not abide by its new rules. Hence, in light of all that I have previously described, what we see happening here is this: the League sought to establish, for once and for all, that organized medicine need not fear the presence of what it now called the "bona fide" birth control clinic. ${ }^{88}$

The shrillness of the organization's attack is striking. "The cause of birth control," wrote ABCL's executive director, Marguerite Benson, in the September 1935 issue of the Birth Control Review, "has reached that stage of development where charlatans, quacks and commercial interests are trying to turn it to profit and ride in upon the wave of popularity." Worse still, in her opinion, was what this meant for the clinic institution itself. As Benson would go on to explain, the "League has received numerous reports of commercial fly-by-nights maintaining 'Birth Control Bureaus' or 'clinics,'” which, as she further warned, unscrupulously preyed on "innocent purchasers." The derisiveness of her words, moreover, is matched only by the frequency of her quotation marks, as they appeared regularly around those terms which designated Irregular birth control facilities. Indeed, although the organization called repeatedly for the establishment of more clinics throughout the nation, it did not suffer lightly the presence of those which failed to conform to its newly established rules. The only solution, then, was what Benson described as "protection," protection which came in part through this new process of certification but also through what this new process of certification yielded: the "certificate" of authenticity, which clinics were then encouraged to display on their reception room walls. ${ }^{89}$

It would be unfair to suggest, however, that the organization's concerns were completely without merit. Much as was the case with the birth control marketplace more generally, there were probably those who wished to take advantage of the situation, either by setting up shoddy clinic operations or by simply pretending that a clinic was indeed a part of their work, even when it was not. In fact, so visible had the concept of the "clinic" become that it appeared regularly in advertisements for commercially-available birth control. ${ }^{90}$ Furthermore, even Rufus Riddlesbarger himself (the birth control entrepreneur who was once Gordon's employer) was not always aboveboard in his advertising techniques. As Andrea Tone has recently noted, it was not a real doctor which graced the cover of one of his most popular birth control pamphlets but rather a fictional one. And as Tone has further pointed out, at least one patient had cause to complain about the improperly-fitted diaphragm she received at his Chicago Medical Bureau clinic. ${ }^{91}$ Problematic as these incidents may be, we must still exercise caution in our indictments against Riddlesbarger and his chain of birth control clinics. In part, because it would be wrong to assume that nobody ever complained about League clinic services, but also because the League's concern was not simply about the quality of clinic services but who it was that was providing them. And nowhere does this appear more vividly than in the organization's implicit discrediting of Riddlesbarger's former employee, Nurse Gordon herself. 
In fact, worth wondering here is just how much Gordon's case served as the final catalyst for this new clinic certification program. Although the issue had come to head in 1935, it was hardly a new idea. As Cathy Moran Hajo has explained, conversations about this process had already begun to take place within the American Birth Control League as early as the mid 1920s, only to grow more complicated, if not also more territorial, upon Sanger's 1929 departure. But 1935 marked nonetheless an important year for both sides of this conflict because it was also in this year when Sanger's group began to issue clinic certification standards of its own. And so, where this particular story is concerned, despite each side's animosities towards each other, there remained with these new sets of rules two important consistencies. First and foremost, both organizations stressed the authority of the physician within the clinic institution. ${ }^{92}$ And second, of course, is the timing of it all. Indeed, it is the timing of these new rules which brings the events surrounding Gordon's case back into focus.

Gordon's predicament in the spring of 1935 constituted a serious liability for those looking to win the backing of the medical profession because, although her case did not make its way onto the pages of the New York Times, it did manage to attract at least some national attention. Worse still were the messages this publicity promoted: that Gordon's clinic was a "legitimate one" (according to Milwaukee's International Labor organization) ${ }^{93}$ that Gordon's work "was in line with the worldwide [birth control] movement" (the Milwaukee Sentinel) $;{ }^{94}$ and that Gordon, as a nurse, was a competent provider of birth control. ${ }^{95}$ Furthermore, that Margaret Sanger herself seemed to be in agreement with these views only made matters worse. Local headlines rang out: "O'Malley Law Case Amazes Mrs. Sanger" and "Margaret Sanger Calls State Behind the Times." 96 Then, too, there was that letter Sanger had written to Gordon, the one in which she emphasized the capabilities of what she called a "good trained nurse," because, as the trial unfolded, Gordon proudly (if not also perhaps strategically) showed this letter for all the world to see, and many in fact did. ${ }^{97}$ It should come as little surprise, then, that Sanger was warned repeatedly by local Milwaukee doctors as well as by those within her own organization to stay away from the Gordon case. But these were warnings which she apparently had little desire to heed. ${ }^{98}$

But it was not just Sanger's show of support which was so threatening; Gordon herself was a force to be reckoned with too. Several months after her acquittal, the Milwaukee nurse would go on a two-week tour to visit birth control clinics across the nation, among them League facilities. And although what she may have said on her various stops is unknown, the presence of this nurse-a woman who was smart, charismatic, and devoted to the cause of birth control-must surely have given at least some clinic workers a moment of pause, a moment to wonder about other possibilities. ${ }^{99}$ Indeed, throughout this whole affair, the American Birth Control League had little interest in promoting her story. When she was arrested, the Birth Control Review said not a word; when she was tried and then acquitted, it kept quiet once again; and when Gordon went, in the fall of 1935, on her clinic-visiting tour, the newsletter's silence persisted. The only thing which did appear was Benson's article lambasting the Irregular clinic movement, and although Gordon was never mentioned by name, what is telling is the date of the article's publication: September 1935, precisely when Gordon was touring the nation. ${ }^{100}$ Hence the only thing more deafening than Benson's 
article was the overall silence of BCR in the months preceding, one which Gordon, in her reading of the Review, may herself have noted.

In the grand scheme of things, however, the League's efforts paid off. While clinics themselves were slow to jump on the certification bandwagon, the AMA finally came around, as in June of 1937, the national medical organization formally recognized "birth control as a legitimate part of medical practice." Significant in the organization's newfound support was what it had to say about birth control clinics themselves. "All [contraceptive providing] dispensaries, clinics, and similar establishments," read recommendation \#4 of the AMA's resolution, should not only "be under legal licensure and supervision" but also "under medical control." 101 Here, then, should we remind ourselves of the efforts of the Illinois State Medical Society, for the wording of this particular resolution bears remarkable resemblance to the rules the state society had several years earlier established for itself and which it hoped the AMA would consider as well. And where contraceptive facilities were concerned, this was what the AMA now did. At long last, then, the American Birth Control League's campaign to get AMA recognition was finally won because not only did the medical organization now back physician-supervised birth control, but it also came out with at least a modest show of support for the institution around which the national birth control organization was based: the birth control clinic itself. ${ }^{102}$

But what of our two nurses: Margaret Sanger and Adele Gordon? Had Sanger continued to throw her weight behind Gordon, the story could have ended quite differently. But this was not to be the case. Just when the publicity surrounding Sanger's involvement was beginning to pick up steam, she was called away to attend to her son who had succumbed to a serious illness. ${ }^{103}$ Four months later (which was, by the way, also four months after the two nurses' last exchange), Sanger's organization would implement its standards for clinic certification. The date: September 1935, the same month as Gordon's clinic tour; the same month also as Benson's blasting indictment of the Irregular birth control clinic movement. For Sanger's supporters, then, those especially who had opposed her endorsement of Nurse Gordon, the illness of her son must surely have come as a blessing in disguise. And so, whether or not Gordon's case did in fact serve as the final catalyst behind this certification process is something for which I leave you decide. But it remains nonetheless an intriguing sequence of events.

With respect to Adele Gordon, an equally compelling story emerges. In the wake of her acquittal, Milwaukee witnessed the emergence of a new birth control organization (the Maternal Health League of Milwaukee), an organization which immediately earned the backing of the American Birth Control League which, in turn, dutifully described its activities on the pages of the Birth Control Review. ${ }^{104}$ What Gordon may have thought of these developments remains unclear. The provision of contraceptives was, in fact, her primary goal, and she did not seem to care who did it, just so long as somebody knowledgeable did. To that end, although it was the more radical groups and commercial organizations which backed her work, she had always sought to enlist the participation of the more conservative groups as well, not least among them the more conservative national birth control organizations. But what she might have thought once they arrived is perhaps another matter. Indeed, what exactly became of Nurse Adele Gordon remains to be seen because, as the city's telephone directory leads 
us to believe, she apparently decided to shut her clinic down. ${ }^{105}$ Perhaps she saw her work as being done; perhaps she did not. But that is a story, a story for another day.

Upon final reflection here, it has occurred to me that one could perhaps argue that this essay in no way challenges what historian Linda Gordon explained some nearly thirty years ago: that, at the heart of the American Birth Control League's efforts to professionalize its work were strategies designed precisely to win over the AMA. In truth, I do not disagree with this interpretation. What I would argue instead, however, is that perhaps the process was not as complete as we have come to believe. For this reason, then, I believe the story I presented here still encourages us to think in new ways. It invites us to imagine the possibilities of this birth control clinic institution; it invites us to imagine its malleability; and it invites us to imagine even more the persistence of such things in the decades to come. Indeed, for all the efforts of the American Birth Control League to contain this institution in its early stages of development, what it would become in the years that followed was in many ways quite different. And this too is a story which remains to be written. But if knowledge of such things still does not excite our imaginations, then at the very least this essay captures here a story for which there is little room in Gordon's path-breaking analysis, that of Nurse Gordon herself.

Department of History

612 Oldfather Hall

Lincoln, NE 68588

\section{ENDNOTES}

For their financial support, many grateful thanks go to the American Institute of the History of Pharmacy, the Illinois Historic Preservation Agency, Radcliffe College's Schlesinger Library, the History and Women's Studies Departments at the University of Illinois at Urbana-Champaign, as well as the Sexuality Research Fellowship Program of the Social Science Research Council with funds provided by the Ford Foundation. I am also deeply indebted to Gretchen Albers, Gail Bederman, Eric Buhs, Jessica Wall, Sarah Webber, the Nineteenth-Century Reading Group of the University of Nebraska-Lincoln, as well as the members of the History of Science, Medicine, and Technology listserv, all of whom lent me their ears throughout the development of this project. Particular thanks, however, goes to Cathy Moran Hajo of the Margaret Sanger Papers Project. Not only did she offer feedback on this piece in its various phases, but it was she who sent the materials regarding the Gordon case my way. Without her good eye (not to mention her remarkable graciousness), this article would never have been written. And finally, for those who wish to contact me directly, I can be reached at rholz2@unl.edu.

1. Linda Gordon, Woman's Body, Woman's Right: Birth Control in America (1976; reprint, New York, 1990), xvii-xviii and chapters 9 and 10. The message remains the same in Gordon's recently revised and updated edition, The Moral Property of Women: A History of Birth Control Politics in America (Urbana, 2002), 3-4 and chapters 9 and 10. So standard has this interpretation become that it also regularly appears in textbooks. For example, Sara M. Evans' Born for Liberty: A History of Women in America (1988; revised edition, New York, 1997), 177 and Sonya Michel and Robyn Muncy's, Engendering America: A 
Documentary History, 1865 to the Present (New York, 1999), 118-19. I must confess too that it is an interpretation which I convey in my classroom as well.

2. It has been suggested to me (and I have long wondered about this myself) that my use of the word "radical" is perhaps a bit misplaced here, that it is perhaps a bit too strong to describe what I hope to convey. All I can say in reply is that my goal with this term is to refer, not only to Sanger's early socialist-feminist politics, but also (and perhaps even more) to the many other features of her early work which could be described as "radical" as well: her faith in a wide variety of providers; her promotion of a wide variety of methods (including abortion); the open-ness of her tactics; as well as the unapologetic frankness of her advice. And so, whether the term's inappropriateness here is the product of any one of the following limitations - of language (and the ways in which the word "radical" has come to be used); of historiography (which has yet to appreciate fully the politics of early twentieth century birth control); or simply of my own (in failing to come up with a better term) - I do not know. But I have chosen to use it nonetheless, though not without an appreciation of the criticisms it might provoke.

3. In what little has been written about these facilities, this is the message which has emerged. In Birth Control Politics in the United States, 1916-1945 (Ithaca, NY, 1994), Carole R. McCann was among the first to mention them, but she does so only in passing (page 183). The most sustained published account comes more recently from Andrea Tone in her book, Devices and Desires: A History of Contraceptives in America (New York, 2001), 166-69. And it is here where we see the interpretation which bears the same sweeping hostility towards these institutions as that voiced by the ABCL and the AMA. It is, I should further add, particularly ironic because throughout much of the rest of the book, Tone offers a much-needed sympathetic portrayal of contraceptive entrepreneurs.

4. Many thanks to Cathy Moran Hajo who suggested the use of this term.

5. The long-standing tensions between Regular and Irregular practitioners has been richly documented. Some examples include: Paul Starr, The Social Transformation of American Medicine (New York, 1982), chapter 3; Ronald L. Numbers, "The Fall and Rise of the American Medical Professions," in Sickness and Health in America: Readings in the History of Medicine and Public Health, edited by Judith Walzer Leavitt and Ronald L. Numbers, 2nd ed., revised (Madison, 1985), 185-196; and Norman Gevitz, ed., Other Healers: Unorthodox Medicine in America (Baltimore, 1988). So too have the tensions between the Regular medical profession and the self-reliant nurse. See Barbara Melosh, "The Physician's Hand:" Work Culture and Conflict in American Nursing (Philadelphia, 1982) and Susan M. Reverby, Ordered to Care: The Dilemma of American Nursing, 1850-1945 (Cambridge, MA, 1987). And finally, equally well-documented are the conflicts between organized medicine and the commercial marketplace, particularly patent medicine providers. See again Starr, The Social Transformation of American Medicine (1982), 127-40 and James Harvey Young, The Toadstool Millionaires: A Social History of Patent Medicines in America before Federal Regulation (Princeton, 1961), especially chapters 13 and 14.

6. Again, McCann and Tone are helpful where clinic standardization is concerned. While McCann mentions it briefly (on pages 182-83 in Birth Control Politics in the United States, 1994), Tone discusses it more thoroughly in chapter 6 of Devices and Desires (2001). I also agree with Tone's conclusion (on page 117) that these standards were born out of ABCL's efforts to distance itself from the commercial marketplace in order to win the support of the AMA, though, as this article suggests, I think the organization was trying to distance itself from other providers as well. 
7. By these other national organizations, I mean Dr. Robert L. Dickinson's National Committee on Maternal Health as well as Margaret Sanger's Clinical Research Bureau.

8. Examples of local affiliate histories include the following: for Arkansas, see Marianne Leung, "'Better Babies:' The Arkansas Birth Control Movement During the 1930s" (Ph.D. diss., University of Memphis, 1996); for Cincinnati, see Kriste Lindenmeyer, "Expanding Birth Control to the Hinterland: Cincinnati's First Contraceptive Clinic as a Case Study, 1929-1931," Mid-America 77 (spring/summer 1995): 145-73; for Massachusetts, see Robyn Rosen, Reproductive Health, Reproductive Rights: Reformers and the Politics of Maternal Welfare, 1917-1940 (Columbus, 2003), chapter 4; for Rhode Island, see Christine E. Nicholl and Robert G. Weisbord, "The Early Years of the Rhode Island Birth Control League," Rhode Island History 45:4 (November 1986): 111-25; for Texas, see Maria Helen Anderson, "Private Choices vs. Public Voices: The History of Planned Parenthood in Houston" (Ph.D. diss., Rice University, 1998) and Denise Annette Hulett, "Every Child a Wanted Child: The History of Planned Parenthood in Waco" (M.A. thesis, Baylor University, 2000); and for clinic building in the Black community, see Jessie M. Rodrique, "The Black Community and the Birth Control Movement," in Passion and Power: Sexuality in History, ed. Kathy Peiss and Christina Simmons (Philadelphia, 1989), 124-39. In this list, however, there are several important exceptions to my generalization. For example, while Rosen reveals how the Boston League co-founder (Blanche Ames) began by the 1930s "to abandon her long-standing commitment to conservatism and marketing birth control as solely a medical matter" (pages 133-4), Rodrique shows how Black birth control organizers regularly resisted white medical models of clinic service. Both of these discussions confirm, therefore, my arguments about the persistence of clinic radicalism and the fuzziness of clinic boundaries.

9. Many thanks to my colleague Ben Rader who suggested this phrase as the title of my piece.

10. Details about Gordon's career (as well as the quotes used above) obtained through Adele Gordon to Margaret Sanger, March 6, 1935, frame 214, reel 108, Margaret Sanger Papers (Library of Congress, Washington, DC). Evidence of her dedication as a student and the admiration she received can be found in "Mrs. Gordon Is Highly Praised by Physician," Milwaukee Leader, April 4, 1935, frame 316, reel 108, Sanger Papers.

11. Address, hours of operation, and times of lectures can be found on the business card for the Milwaukee Medical Bureau (on frame 248). For extension of hours to serve the poor, see "Special Notice" (frame 229A). Records also reveal that in the clinic's first six months of operation, a total of 68 relief patients were served. Among them, 23 were served for free. See "Report on Relief Patients Up to February First 1933," frame 228. All on reel 108, Sanger Papers. Thanks also to my colleague Tim Mahoney, whose grandfather once served as the manager of the Plankinton Arcade Building, for pointing out to me the significance of this Milwaukee landmark.

12. Details regarding the background of Gordon's patients taken from "Report on Three Hundred Cases," February 1933, frame 229B, reel 108, Sanger Papers. Percentages calculated by myself. Descriptions of League clinic patients appear throughout the Birth Control Review (BCR). For Chicago, see "State Organizations for Birth Control. Illinois Birth Control League," BCR 14 (September 1930): 259-60. For the number in attendance at one of Gordon's lectures, see Adele Gordon to Margaret Sanger, February 8, 1935, frame 210, reel 108, Sanger Papers. 
13. Gordon to Sanger, March 6, 1935. Copy of the O'Malley bill can be found in volume 861, reel 127, American Civil Liberties Union Papers, Seeley Mudd Library (Princeton University Library, Princeton, New Jersey).

14. Details gleaned from Gordon to Sanger, March 6, 1935 and Adele Gordon to Margaret Sanger, March 13, 1935, frames 243B-45, reel 108, Sanger Papers. Quote from letter dated March 13. Specific reference to the hostility Gordon faced from women's groups can be found in Lucina Irish Brown to Miss Marguerite Benson, March 13, 1935, frame 216 and Gordon to Sanger, March 13, 1935, frames 243B-45. Both on reel 108, Sanger Papers.

15. "Birth Control 'Sales' Denied," [unmarked newspaper clipping], April 4, 1935, frames 280-81, reel 108, Sanger Papers.

16. Gordon to Sanger, March 13, 1935. For ABCL's efforts to distance the term "birth control" from abortion, see Leslie J. Reagan, When Abortion Was a Crime: Women, Medicine, and Law, 1867-1973 (Berkeley, 1997), 36-37 and 141. For the League's efforts to distance the term from sex among the unwed and the marketplace, see my dissertation, Rosemarie Petra Holz, "The Birth Control Clinic in America: Life Within; Life Without, 1923-1972" (Ph.D. diss., University of Illinois at Urbana-Champaign, 2002), 14-15 and chapter 2.

17. One example of these tabulations can be found in "Report on Relief Patients Up to February First 1933," frame 228, reel 108, Sanger Papers. But other such reports can be found elsewhere on the reel.

18. See Lucina Irish Brown, "Report on the Trial of Adele Gordon," April 6, 1935, frame 284, reel 108, Sanger Papers.

19. Gordon to Sanger, February 8, 1935.

20. Margaret Sanger, My Fight for Birth Control (1931; reprint, New York: Maxwell Reprint Company, 1969), 144.

21. Materials regarding the Medical Bureau's chain of facilities can be found in Lanteen, folders 2-4, box 465, Historical Health Fraud and Alternative Medicine Collection (Archives of the American Medical Association, AMA Building, Chicago, Illinois). Figures for the Medical Bureau's caseload have been drawn from Dr. Robert L. Dickinson to Dr. Morris Fishbein, February 11, 1930, folder 3, box 465, Lanteen, Historical Health Fraud Collection and Lanteen Laboratories, Inc. v. Clark, 294 Ill. App. 81 (1938); 13 N.E. (2d) 678.

22. See listings in the 1936 and 1938 Chicago Telephone Directory, Social Sciences Division (Chicago Public Library: Harold Washington Library Center, Chicago, Illinois). Materials regarding the Woman's Bureau can also be found in the AMA's Historical Health Fraud and Alternative Medicine Collection. See Woman's Bureau, folder 5, box 917.

23. Secretary to Mrs. Sanger [Florence Rose] to Rufus Riddlesbarger, March 1, 1933, frame 694, reel 57, Sanger Papers and Los Angeles City Directory, 1929 (Los Angeles Directory Company, 1929), 1584. The listing in the Los Angeles directory reads: "Mother's Clinic Inc." Its name, therefore, suggests that it had commercial connections; its Director (Nurse Freda Frost) suggests that a nurse was in charge. For another possible reference to an Irregular clinic, see Rita Irwin and Clementina Paolone, Practical Birth Control: A Guide to Medically Approved Methods for the Married (New York, 1937), 158. 
24. For emphasis on doctors inside American clinics, see Hannah M. Stone, "Clinical Birth Control Abroad," BCR 11 (December 1927): 321-22 and Alice C. Boughton, "To Start a Clinic," BCR 1 (April 1934): 2.

25. As Gordon's work reveals, this was often the case in the Medical Bureaus. She worked on her own but in consultation with the Bureau's chief physician, who made weekly visits from Chicago. See "Birth Control 'Sales' Denied," April 4, 1935. What is striking is how this practice resembles the early twentieth century calls to justify the use of trained midwives to oversee uncomplicated deliveries. See Frances E. Kobrin, "The American Midwife Controversy: A Crisis of Professionalization" (1966), reprinted in Women and Health in America: Historical Readings, edited by Judith Walzer Leavitt (Madison, 1984), 318-26 and Judy Barrett Litoff, American Midwives: 1860 to the Present (Westport, 1978), chapters 6 and 7 .

26. For Dr. Blood's involvement, see the AMA's form letter replies (also in folder 5) to those inquiring about the clinic. But it is also possible that the clinic may have been first begun by nurses. See Woman's Bureau pamphlet, "Feminine Hygiene," 1935, folder 5, box 917, Historical Health Fraud Collection.

27. Quote from Helen Carpenter, Annual Report of the Illinois Birth Control League, April 29, 1925, folder 8, box 390, Welfare Council Papers (Chicago Historical Society, Chicago, Illinois).

28. For Lanteen's radio shows, see Dr. F. Hewitt to the AMA, April 5, 1929, folder 3, box 465, Lanteen, Historical Health Fraud Collection. For form letters mailed out to private citizens, see Horner F. Sanger to Dr. Cramps, December 24, 1929 and "Dr. Mary Hall to Dear Madam" (1930). For form letters mailed out to doctors, see "Rufus Riddlesbarger to Dear Sir," August 21, 1930. All in Lanteen, folder 3, box 465, Historical Health Fraud Collection. Letters, describing the ads picked up in local drugstores, came from Illinois, Michigan, Maryland, Ohio, New York, and New Jersey. See letters to AMA in Lanteen, folders 2-4, box 465, Historical Health Fraud Collection. For Lanteen flier in box of sanitary napkins, see William G. Mather, Jr. to Dr. Morris Fishbein, July 22, 1938, Lanteen, folder 4, box 465, Historical Health Fraud Collection.

29. For description of leafleting, see the Woman's Bureau calling card and the handwritten note on its margin. For stacks of fliers left in downtown office buildings, see the letter of complaint written by George Nichols to States Attorney Courtney, February 1, 1935. For an example of the flier itself, see "Feminine Hygiene," 1935. All in Woman's Bureau, folder 5, box 917, Historical Health Fraud Collection.

30. Quote from Carolyn Bryant, "The Clinic Interview," BCR 1 (April 1934): 4.

31. R.H.S., "Advice Given by Doctor Buzza," n.d. [1930], Lanteen, folder 3, box 465, Historical Health Fraud Collection.

32. One 1930 report placed the fee at $\$ 8.25$, while another indicated $\$ 11$. See, respectively, Dr. H.E. Hickman to AMA, January 17, 1931 and Untitled, n.d. [1930], both in Lanteen, folder 3, box 465, Historical Health Fraud Collection.

33. Medical Bureau prescription form, frame 232A, reel 108, Sanger Papers.

34. Rufus Riddlesbarger to Margaret Sanger, March 7, 1933, frame 695, reel 57, Sanger Papers. 
35. Mary M. White, "Maintaining Clinic Standards," BCR 16 (October 1932): 1 and Gladys Gaylord, "Clinical Aspects of Birth Control," BCR 17 (July 1933): 166. Quote from Gaylord.

36. Note, for example, the differences between the report submitted to the conservative Welfare Council of Chicago (cited previously) and that which went to Mary Ware Dennett's organization, the more liberal Voluntary Parenthood League. For the latter, see Annual Report of the Illinois Birth Control League, April 30, 1930, frames 454-459, reel 17, Papers of Mary Ware Dennett and the Voluntary Parenthood League (Women's Studies Manuscript Collection, Schlesinger Library, Radcliffe College, Cambridge, MA).

37. According to one source, League clinic fees ranged from $\$ 10$ to $\$ 15$. See Alice Boughton, "To Start a Clinic," BCR 1 (April 1934): 2. Records from the Illinois Birth Control League reveal, however, that they usually charged those who could afford to pay \$7.50. See Report of the Membership Committee of the Chicago Council of Social Agencies, Regarding Application for Membership of the Illinois Birth Control League, 1929, folder 8, box 390, Welfare Council Papers.

38. Ellen Chesler, Woman of Valor: Margaret Sanger and the Birth Control Movement in America (New York, 1992), 300-03.

39. The names of the Irregular clinics include: Bureau of Birth Control Information, Medical Bureau of Birth Control Information, and Woman's Bureau of Birth Control Information. Also in this list is the Mothers' Birth Control Clinic, which was what Riddlesbarger first used before adopting the name Medical Bureau. All the rest designate League facilities and were taken from "Birth Control Clinics at Work," BCR 14 (February 1930): 48-9 and Bernice J. Guthmann, The Planned Parenthood Movement in Illinois (Chicago, Planned Parenthood Association-Chicago Area, 1965), 4. Notable too is the fact that League clinics often changed their names as well. See again Guthmann (p. 4).

40. Charles E. Rosenberg, "Social Class and Medical Care in Nineteenth-Century Afmerica: The Rise and Fall of the Dispensary," Journal of the History of Medicine 29 (January 1974): 32-54. Quotes from page 32. For more on the popularity of the dispensary in the first few decades of the twentieth century, some of the problems embedded within this institution, as well as physicians' growing opposition to it, see Beatrix Hoffman's recent study on health insurance reform, The Wages of Sickness: The Politics of Health Insurance in Progressive America (Chapel Hill, 2001), 19-20 and 70. For more on the dispensary's decline, see also David Rosner's A once charitable enterprise: Hospitals and health care in Brooklyn and New York, 1885-1915 (Cambridge, 1982), chapter 6.

41. Dr. Charles H. Parkes, "The Clinic Habit," Illinois Medical Journal 67 (April 1935): 354-57. Hereinafter referred to as IMJ.

42. Dr. Dean Lewis, "The Place of the Clinic in Medical Practice," Journal of the American Medical Association 100 (June 17, 1933): 1905-10. Hereinafter referred to as JAMA.

43. "Ultimately the Clinic Will Prove to be Another Example of the Cure Being Worse than the Disease," IMJ 62 (July 1932): 4-5. Quote on page 4. For more on this sense of the clinic's bastardization, see also Dr. E.O. Laughlin, "The Encroachment of Free Clinics," IMJ 56 (August 1929): 87-8.

44. On this "new" institution of the twentieth century, historians have begun to develop an important body of scholarship. For several discussions of clinics more gener- 
ally (with mention also of the medical profession's hostility to the institution), see Paul Starr's The Social Transformation of American Medicine, 191-197 and George Rosen's The Structure of American Medical Practice, 1875-1941 (Philadelphia, 1983), 32-36, 50-51, 97-98. Worth noting in Rosen's work is how his discussions of the clinic and the dispensary overlap, making it difficult to determine the difference between the two. But many others have focused on specific types of clinics: on well-baby clinics, see Lynn Curry's Modern Mother in the Heartland: Gender, Health, and Progress in Illinois, 19001930 (Columbus, 1999), 18, 36, 47, 57, 126; on social hygiene/venereal disease clinics, see Allan M. Brandt, No Magic Bullet: A Social History of Venereal Disease in the United States Since 1880 (New York, 1987), 43-45 and 147 and Catherine Batza, "Before AIDS: The Relationship Between the Chicago Gay Community and Medical Communities, 1974-1982" (paper presented at the Missouri Valley History Conference, Omaha, Nebraska, March 2004); and on abortion clinics, see Reagan, When Abortion Was a Crime, chapter 5 and passim.

45. Interestingly, although David Rosner suggests the existence of commercial connections inside the local dispensary (A once charitable enterprise, chapter 6), commercial sponsorship of clinics has gone largely unnoticed. For one example of these sorts of arrangements, see Dr. Charles P. Blair, "Medical Societies Can Operate Their Own Special Clinics," IMJ 61 (May 1932): 412-13. Here Blair describes a crippled children's clinic which was conducted in cooperation with a brace-making firm.

46. As one editorial would state, "many of our doctors are bitter in their denunciations of the unfair competition offered by the Billings Hospital and the University of Chicago clinics, among others." In "Editorials. Many Complaints Are Heard Regarding Unfair Medical Competitions," IMJ 64 (July 1933): 1-3. Quote from page one. See also Dr. Joseph K. Narat, "A Rush Call for Creation of Cooperative Clinics," IMJ 59 (June 1931): 461-66. His discussion on page 463 also criticizes those clinics associated with teaching institutions. For more on the growth of hospitals more generally, see Charles Rosenberg, The Care of Strangers: The Rise of America's Hospital System (New York, 1987) and Morris Vogel, The Invention of the Modern Hospital, 1870-1930 (Chicago, 1980).

47. "Society Proceedings. Report of the Editor of the Illinois Medical Journal," IMJ 44 (July 1923): 60.

48. "Editorial. Resolutions Passed by the Council of the State Medical Society, December 1924," IMJ 47 (January 1925): 11-12.

49. The explicit ban on treatment was one part of these stricter rules; the assertion of the authority of Regular doctors was the other.

50. George Thomas Palmer, "Reasonable Regulation of Clinics," IMJ 47 (January 1925): 32-34. Quotes from page 33.

51. "The Clinic Situation from the Standpoint of the Illinois State Medical Society," IMJ 52 (August 1927): 95.

52. "New Business," Report for the AMA's 1929 annual meeting held in Portland, Oregon, JAMA 93 (July 20, 1929): 203.

53. "Reports of Officers: Corporation Practice," Report for the AMA's 1929 annual meeting held in Portland, Oregon, JAMA 94 (May 17, 1930): 1596. 
54. "Report of Councilor Sixth District. Illinois State Medical Society Proceedings of the House of Delegates," IMJ 66 (July 1934): 20.

55. "Woman's Auxiliary to the Illinois State Medical Society," IMJ 59 (April 1931): 248-49. Quote from page 249.

56. "Resolution on Contraception," Proceedings of the AMA's 1927 annual meeting held in Washington, DC, JAMA 88 (June 4, 1927): no page number.

57. Medical News. Maryland," JAMA 89 (October 1, 1927): 1157-58.

58. "Medical News. New York City. Academy Considers Raid Menaces Freedom of Profession," JAMA 92 (May 4, 1929): 1530-31 and "Medical News. New York City. Judge Frees Birth Control Clinic Physicians," JAMA 92 (June 1, 1929): 1872.

59. Details from the two women's February 19th visit, as well as the raid which followed, taken from the following documents: Lucina Irish Brown to Marguerite Benson, March 13, 1935, frames 216-17; Gordon to Sanger, March 13, 1935; "Adele Gordon Airs Views on Birth Control," Milwaukee Sentinel, April 4, 1935, on frame 315; and "Arrest Two as Violators of Birth Control Statute," unmarked newspaper clipping, on frame 250. All on reel 108, Sanger Papers. Quotes from Gordon in her letter to Sanger. See also George A. Bowman to Samuel Paul Puner (of the ACLU), April 5, 1935, volume 861, reel 127, ACLU Papers.

60. Conflicting reports include Bowman to Puner, April 5, 1935; Lucina Irish Brown to Marguerite Benson, March 13, 1935, frames 216-17, reel 108, Sanger Papers; and "Arrest Two as Violators of Birth Control Statute," unmarked newspaper clipping, on frame 250, reel 108, Sanger Papers.

61. "Women Crowd Birth Control Trial," Milwaukee Journal, April 3, 1935, on frame 276, reel 108, Sanger Papers.

62. Gordon to Sanger, March 13, 1935.

63. Bowman to Puner, April 5, 1935.

64. "Arrest Two as Violators of Birth Control Statute," unmarked newspaper clipping, on frame 250, reel 108, Sanger Papers.

65. Untitled flier, n.d. [circa March 1935], frame 221B, reel 108, Sanger Papers.

66. "To the Voice of the People," March 9, 1935, frame 232B and Mrs. M.C. Weston, "To the Editor. A Misnomer," Milwaukee Journal, March 23, 1935, on frame 257. Both on reel 108, Sanger Papers.

67. Local newspaper clippings can be found throughout reel 108 of the Sanger Papers.

68. Adele Gordon to Margaret Sanger, March 18, 1935, frames 239-240, reel 108, Sanger Papers.

69. Cora Meyer to the American Civil Liberties Union, March 25, 1935, volume 861, reel 127, ACLU Papers. 
70. Lucina Irish Brown to Marguerite Benson, March 13, 1935, frames 216-17, reel 108, Sanger Papers.

71. Margaret Sanger to Adele Gordon, February 18, 1935, frame 211A, reel 108, Sanger Papers.

72. Margaret Sanger to Adele Gordon, March 9, 1935, frame 189, reel 108, Sanger Papers.

73. Gordon to Sanger, March 13, 1935.

74. Adele Gordon to Margaret Sanger, March 18, 1935, frames 239-240, reel 108, Sanger Papers.

75. Adele Gordon to Margaret Sanger, March 23, 1935, frame 255, reel 108, Sanger Papers.

76. Among the organizations they contacted were the League of Women's Voters and the American Association of University Women. See Stella Hanau to Mrs. W.A. Norris, March 25, 1935, frame 263 and Stella Hannau to Mrs. Laun, March 25, 1935, frame 263B. Both on reel 108, Sanger Papers. For initial discussion of the plans to speak at a rally, see Gordon's letter to Sanger (on which Sanger scribbled some notes) dated March 23, 1935, frame 255, reel 108, Sanger Papers. More discussion about this proposed rally appears elsewhere in the reel. It appears, however, that the rally never took place.

77. Margaret Sanger to Dr. Arnold E. Erling, April 9, 1935, frame 283, reel 108, Sanger Papers.

78. Indeed, though some women's organizations members expressed an interest in birth control to Sanger and her people, when Gordon herself tried to contact them, all efforts "were futile." See, respectively, Dorothy Barker Norris (president of Milwaukee County League of Women Voters) to Miss Stella Hanau, April 3, 1935, frame 154B and Adele Gordon to Stella Hanau, October 9, 1935, frames 290B-291. Both on reel 108, Sanger Papers. Quote from Gordon's letter to Hanau.

79. Bowman to Puner, April 5, 1935.

80. Adele Gordon to Margaret Sanger, April 8, 1935, frames 286-87, reel 108, Sanger Papers.

81. "Birth Control Jury Frees Woman Here," Milwaukee Journal, April 4, 1935, frame 274, reel 108, Sanger Papers.

82. Lucina Irish Brown, "Report on the Trial of Adele Gordon," April 6, 1935, frame 284 , reel 108, Sanger Papers. Indeed, the judge's sympathy for Gordon's case can be found throughout the proceedings as he regularly ruled in her favor when the prosecution sought to silence her impassioned speeches. See, for example, his remarks as described by Lucina Irish Brown in her "Report on the Trial of Adele Gordon."

83. The full extent of this trial gleaned from the following accounts: "Birth Control 'Sales' Denied," 4 April 1935; "Birth Control Jury Frees Woman Here," Milwaukee Journal, April 4, 1935, frame 274; "Mrs. Gordon Freed in Birth Control Case," Milwaukee Leader, 5 April 1935, frame 307; "Jury Frees One in Birth Control Case; Women Weep," Wisconsin News, April 4, 1935, frame 309; Adele Gordon to Margaret Sanger, April 8, 
1935, frames 286-87; and Brown, "Report on the Trial of Adele Gordon." All on reel 108, Sanger Papers. See also Bowman to Puner, April 5, 1935.

84. Telegram from Adele Gordon to Margaret Sanger, April 18, 1935, frame 286A, reel 108, Sanger Papers.

85. "Jury Frees One in Birth Control Case; Women Weep," April 4, 1935.

86. ABCL Board Meeting Minutes, April 25, 1935, frame 30, reel 28, Sanger Papers. According to Cathy Moran Hajo of the Margaret Sanger Papers Project, despite earlier conversations about certification, this was also the first time the League's board took this anti-commercial stance.

87. "Minimum Standards for Clinics Affiliated with the American Birth Control League and Member Organizations." In How to Start a Contraceptive Center: Suggestions Offered by the American Birth Control League, n.d. [circa 1936], folder 1, box 80, Planned Parenthood Federation Papers I, Sophia Smith Collection (Smith College, Northampton, Massachusetts).

88. The term "bona fide" drawn from Marguerite Benson, "Leaping on the Bandwagon. A Caution to Bona Fide Birth Control Organizations," BCR 3 (September 1935): 5-6. This term also appears in Practical Birth Control: A Guide to Medically Approved Methods for the Married (New York, 1937), 158.

89. Benson, "Leaping on the Bandwagon" (September 1935): 5. Birth control manuals would soon echo such sentiments, even down to the use of quotation marks. See, again, Irwin and Paolone, Practical Birth Control (1937), 158-59.

90. For a discussion of the 1930s birth control marketplace more generally, see Andrea Tone, "Contraceptive Consumers: Gender and the Political Economy of Birth Control in the 1930s," Journal of Social History 29 (spring 1996): 485-506 and Holz, "The Birth Control Clinic" (2002), chapter 2. In this chapter I also discuss the significance of the term "clinic," particularly in advertising campaigns.

91. Tone, Devices and Desires, 166-69.

92. Cathy Moran Hajo, "What Every Woman Should Know: Birth Control Clinics in the United States, 1916-1939” (Ph.D. diss., New York University, forthcoming).

93. Cora Meyer to the American Civil Liberties Union, March 25, 1935, volume 861, reel 127, ACLU Papers.

94. “Adele Gordon Airs Views on Birth Control," frame 108, reel 315, Sanger Papers.

95. "Mrs. Gordon Is Highly Praised by Physician," Milwaukee Leader, April 4, 1935.

96. “O’Malley Law Case Amazes Mrs. Sanger,” Milwaukee Leader, March 28, 1935 and "Margaret Sanger Calls State Behind the Times," Milwaukee Journal, March 31, 1935. Both on frame 292, reel 108, Sanger Papers.

97. Although Gordon explained how Sanger's note was intended to be shown only to those "directly interested" in her case, it got considerably more publicity than that because, as she would further explain, she had received "many requests" for the articles and newspaper clippings relating to her case. See Adele Gordon to Stella Hanau, October 9, 
1935, frame 290B-291, reel 108, Sanger Papers. The letter was also published in at least one local newspaper (the Milwaukee Leader, March 21, 1935). See letter and attached newspaper clipping in Adele Gordon to Sanger, March 22, 1935, frame 265B, reel 108, Sanger Papers.

98. Memo from Stella Hanau to Margaret Sanger, Regarding Dr. Leon Cole's Attitude Regarding Gordon Case, April 5, 1935, frame 209A and Dr. Arnold E. Erling to Margaret Sanger, April 6, 1935, frame 282. Both on reel 108, Sanger Papers. See also Sanger's angry comments, which appeared on the margins of a letter from Gordon discussing Sanger's possible attendance at the local labor rally, saying that she would attend "at her own expense." Adele Gordon to Margaret Sanger, March 23, 1935, frame 255, reel 108, Sanger Papers.

99. Adele Gordon to Mrs. Stella Hanau, October 9, 1935, frames 290B-291, reel 108, Sanger Papers.

100. Benson, "Leaping on the Bandwagon" (September 1935): 5-6. Although neither Gordon nor the Medical Bureaus of Birth Control of Information were referred to directly, the article warned readers to be particularly wary of what it called: "Birth Control Bureaus."

101. For slowness of clinic certification, see "Birth Control Marches On," BCR (February-March 1937): 3. For the AMA's birth control resolution, see "American Medical Association Accepts Birth Control," BCR 4 (June 1937): 1-2. Quote on page 1. Italics mine.

102. As Carole McCann has demonstrated, however, the AMA's support for the birth control clinic remained extremely cautious, both at the time of the resolution and in the decades that followed. See pages 94-95 in Birth Control Politics in the United States. However, given the profession's uncertainty about clinics in general, I would argue that the organization's resolution marked a significant moment nonetheless.

103. Stella Hanau to Lucina Irish Brown, April 26, 1935, frame 158B, reel 108, Sanger Papers.

104. Discussion of this new birth control organization can be found in Mrs. William A. Norris to Stella Hanau, April 3, 1935, frame 154B and Hanau's reply, April 8, 1935, frame 154A. BCR's announcement of this new organization can be found in "Milwaukee Center Expands Program," BCR 3 (January 1936): 8.

105. While the Medical Bureau appears in 1935, it does not in subsequent years, suggesting that the facility may have indeed closed down. See Wright's Milwaukee City Directory (Wright Directory Company, Publishers). Other Irregular clinics seem to have stayed open however. For evidence of the continued operation of the Medical Bureau of Chicago, see Oliver Field to Dr. Smith, May 19, 1948, folder 4, box 465, Lanteen, Historical Health Fraud Collection. For the continued operation of the (chiropractor-run) Woman's Bureau, see “'Mentally Ill' Clients Gets Some Advice," Chicago Daily News, July 3, 1964, p. 1. 